\title{
DESIGN WEBSITE AND MOBILE APP WITH E-COMMERCE AND DIGITAL MARKETING OF MICRO SMALL AND MEDIUM ENTERPRISES (MSMES) HYDROPONICS IN BANDUNG CITY
}

\author{
Davy Ronald HERMANUS ${ }^{1 *}$, Yovanka DAVINCY ${ }^{2}$, Bryan GHILCHRIST ${ }^{3}$, and Jajat SUDRAJATA ${ }^{4}$ \\ ${ }^{1}$ Department of Computer Science, Indonesia \\ ${ }^{2,3}$ Bina Nusantara University Bandung, Indonesia \\ ${ }^{4}$ Department, Faculty of Economics and Communication, Bina Nusantara University, Jakarta, Indonesia \\ *davy.hermanus@binus.ac.id, jsudrajat@binus.edu, yovanka.setiawan@binus.ac.id, bryan.ghilchrist@binus. \\ ac.id
}

\begin{abstract}
Currently, most of the small business in Indonesia are in struggle because of Covid 19 Pandemic so the government encourage any activity to help Micro, Small and Medium Enterprises (MSMEs) in any provinces. Beside it, certain hydroponic communities surrounding city of Bandung were formed in purpose to enlarge the activities of the planting and harvesting of hydroponic media. Some prefer to think it as a hobby by planting them in the front or back of their home but other members want to develop a small hydroponic industry such as MSMEs. One that is being developed is the MSME group located in Cileles Village, Jatinangor District, Sumedang Regency, West Java. Although Sae Garden Farm hydroponic business has reached the stage of producing tens of thousands of vegetable plants per month, they cannot regularly supply them successfully to their customers. In fact, they need an online site that can promote and sell their products. In addition, this business requires better management of information systems known as a digital marketing. Our plan is to assist Sae Garden Farm SMEs to create a website, a mobile application and continue it with digital marketing. Our first stage will be to build a website followed by building an Android-based application (Mobile App) and it will be combined with strong Digital Marketing which can later be continuously developed by Sae Garden Farm SMEs. We hope that in the future various Hydroponic communities throughout Greater Bandung can work together so that through this community development activity, many people will benefit in the middle of the Pandemic of Covid- 19 .
\end{abstract}

Keywords: UMKM, E-Commerce, Community, Covid-19 Pandemic, Hydroponic, Digital Marketing

\section{BACKGROUND}

Sae Garden Farm Hydroponics has been established since early 2019 after the West Java provincial government boosted the Urban Farming program to the community. Sae Garden Farm is in Jatinangor that is not in the center of the city but on the stubborn of Bandung. Its location is on a hill near a beautiful rice field, so it is not contaminated with traffic pollution. Currently, it has two gardens that contain 500 holes and 10.000 holes of hydroponic pipes. There are two more gardens with a capacity of 4000 holes each under construction.

The Harvest is usually programmed to be cultivated every two weeks. Sae Garden Farm mainly products are hydroponic vegetables, plant seeds, hydroponic nutrition, hydroponic house construction for gardener and industry. It also provides just for services for customers who need to build hydroponic systems both on a home scale and on an industrial scale.

Sae Garden Farm sells crops mainly through an offline model through various hydroponic lovers' communities who provide information on the needs of customers. Communication is usually through WhatsApp Application group.

There are a lot of information recently about how to build a hydroponic garden at home. The titles of the information are sometimes found interesting to the readers and often challenge them to build a greenhouse near their house with hydroponic system[1][2][3].

There also many free e-books in internet that new hydroponic hobbyist can download them easily by browsing [4] [5] [6]. Someone may also choose the better way to plant between the soil system or hydroponic system
[7]. Moreover, it give someone a challenge to create a new business in food production using Hydroponic vegetables or fruits [8] or enriched the searching of new healthy vegetables recipes [9]. For them who want to find good nutrition for hydroponic plant should read the advice of Muckle [10]. Finally the most important for MSMEs is how to sell their products successfully [11].

Fortunately, the Government of Indonesia always encourage MSMEs and all cooperation (Koperasi) to enlarge and to expand their business and do not think to compete with large enterprise [12]. The policy of Government opens many doors that MSMEs should grow together with industries, companies or startups. One example, Tokopedia and Kemkominfo (Ministry of Communication and Information Indonesia) opened a training named "Go Digital" to support MSMEs [13]. Even MSMEs is pushed to go International [14].

Although these strategies are looking good and can make much benefit to MSMEs, in practices they have an enough strong resistance to move forward because of the pandemic making the program postponed. It looks like that all companies both large and small are now looking forward to receiving the good benefit to keep going in business [15] by using Digital Marketing [16].

Digital marketing is a form of effort to promote and market a brand using digital media, such as the internet. Digital marketing is now a very popular strategy and is used by most marketers around the world. This is the impact of the increasing world of internet and technology that makes the internet a very prospective market [17]. Moreover, traditional market can run together with Digital Marketing [18]. 
In concerning with education field, especially in marketing education, student should combined design thinking with digital marketing [19] and minimize the gap of the knowledge and demand of skilled staff in any country [20]. An example of Digital Marketing is how to promote the company's brand by using social media [15] [21]

\section{METHOD}

First, this paper was constructed by some literature reviews that need to support an MSMEs in pursuing the dreams to achieve ROI in Pandemic time especially for Hydroponic business. Second, it will be included the steps to support Sae Garden Farm to enter in online business with standard professional that can compete with other similar business. We added an example model how a team from community Development University like Binus University can work together with Sae Garden Farm with only one year support and give the rest for them to be in charge their own business in the following year

The steps to follow are:

1. Visit the owners and their farm to talk about their current situation and dreams and plan in couple years. Take picture videos and note the requirement of the owner.

2. Listing the product and services that the owners want to sell either via offline market or via online market.

3. Analyze their problem and find out the solution that can help them.

4. If they do not want to have a website nor a mobile app, the team will start to develop both with priority scale.

5. In case of number 3 above If they already have one, we will discuss if they want to use it or design a new one.

6. Regarding number 4-part a, if they already have it and do not want to use the former website, the team will design and build a new website and will postpone the design of mobile app.

7. Regarding the second case of the question number 4. If they already have it and want to use that old website, the team will not build a new website but will continue immediately to design and build a mobile app.

1. Above all the team will make sure that Sae Garden has four social media social: Facebook, Instagram, YouTube and Twitter because the team will work with Digital Marketing using these accounts. For one month the team will do digital marketing to promote website of Sae Gardenfarm.com

2. The next step the team will help to promote the website or mobile app of Sae Garden Farm and gather all the result.

3. After one month the team will analyze and evaluate it and choose the best way to be continue in next promotion.

4. Last step the team will write a report and give the guidance for Sae Garden Farm in order they can take a baton to continue the business.

5. After these activities, our team and Binus University will monitor to help Sae Garden Farm and look forward to helping them with another community development team in next following year.

\section{RESULT AND DISCUSSION}

\section{Problems:}

They have several problems in marketing their products. Their current website does not have enough visitors and lack of engagement from regular customers. Although they have many plantations and many vegetables products every month due the exiting great houses, they cannot bring them to the market.

Furthermore although they have a great location plus good price and good place they have not strong in promotion.

\section{Problem Solution}

The team from Binus University will help Sae Garden in building an Online System Information and Digital Marketing by developing New Website and New Mobile App. In this cooperation the team will continue to market the products and services of Sae Garden Farm for two months. The members of team consist of Lecturer and Student who have knowledge and skill in Business Management and Computer Science

\section{The Products and Services}

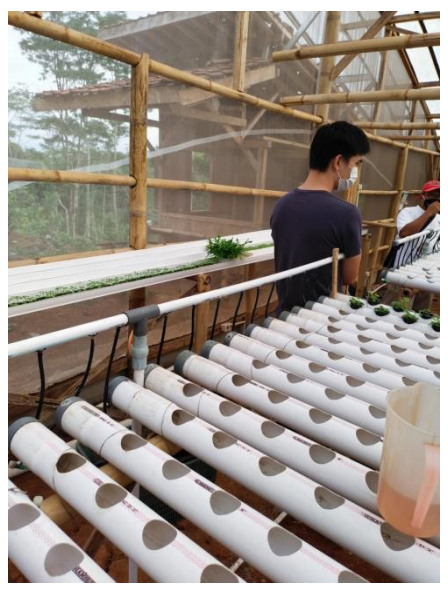

Figure 1. One of Green House in Sae Garden Farm

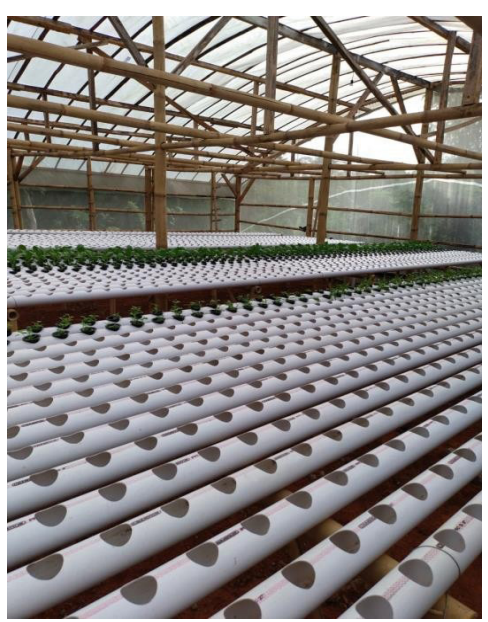

Figure 2. Pipe and holes of Sae Garden Farm 


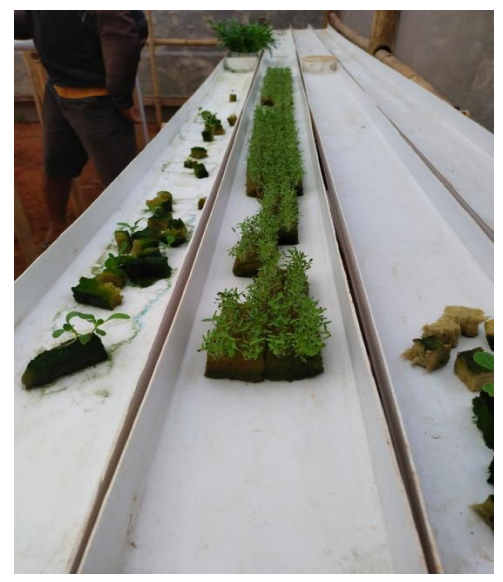

Figure 3. Rockwall

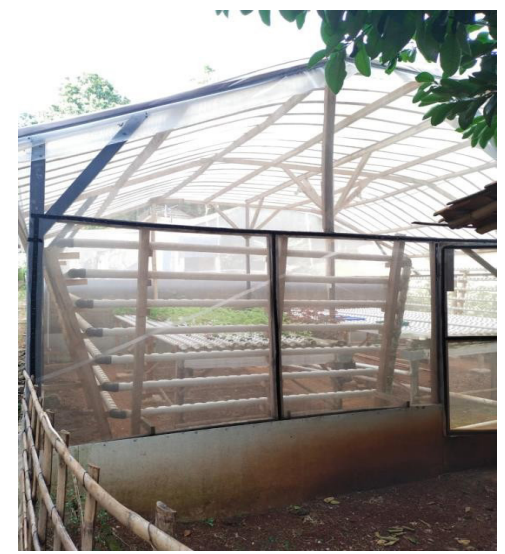

Figure 4. Another Green House Construction

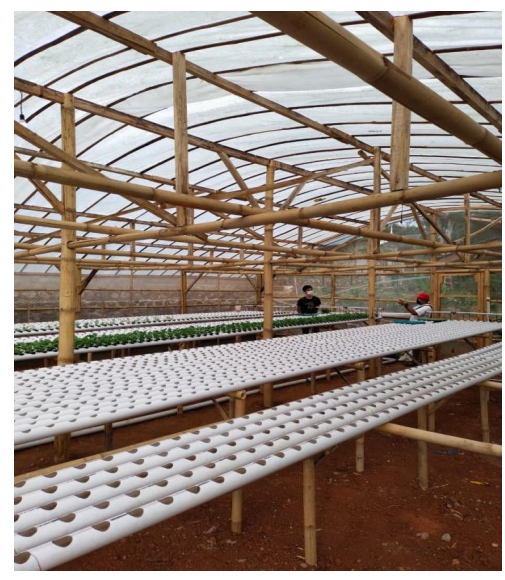

Figure 5. 10.000 holes to be planted

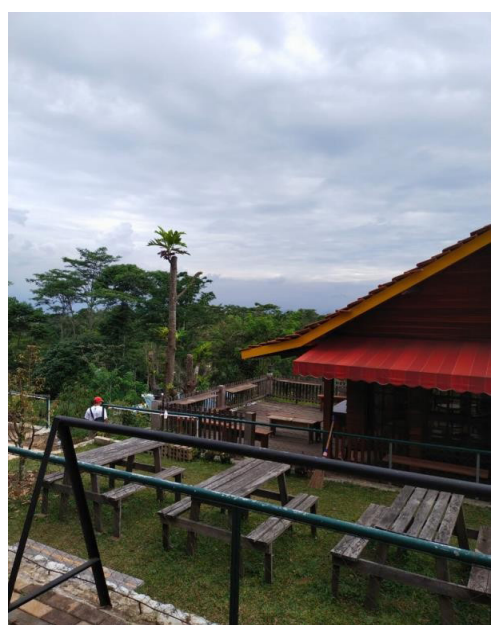

Figure 6. Better view for visito

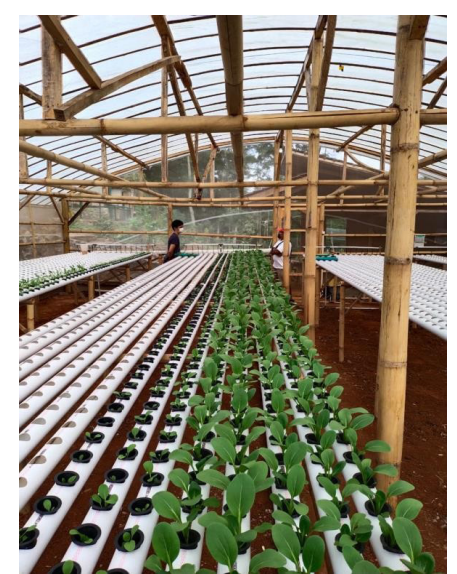

Figure 7. Two weeks vegetable plants

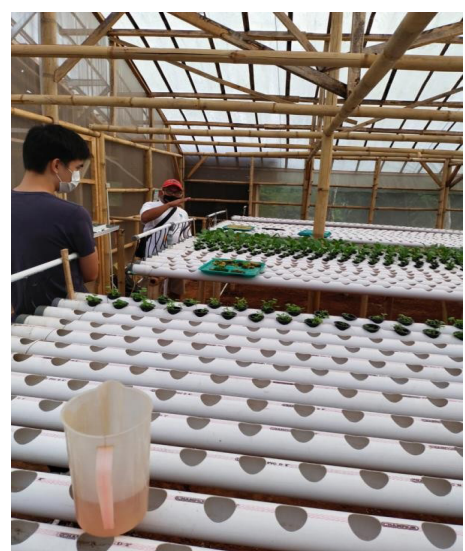

Figure 8. The Owner Mr. Dani Sapari explained the Figure

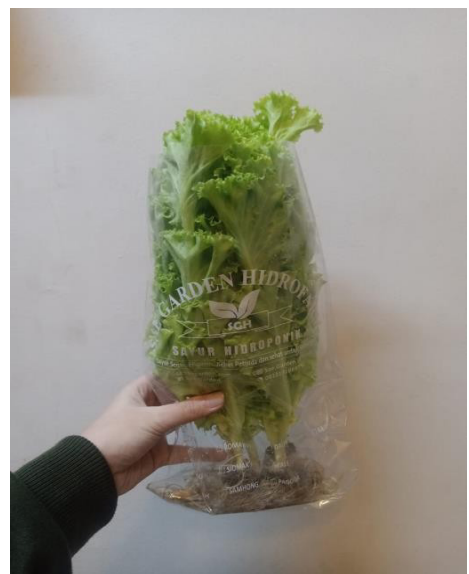

Figure 9. The plant in package to be sold (Selada)

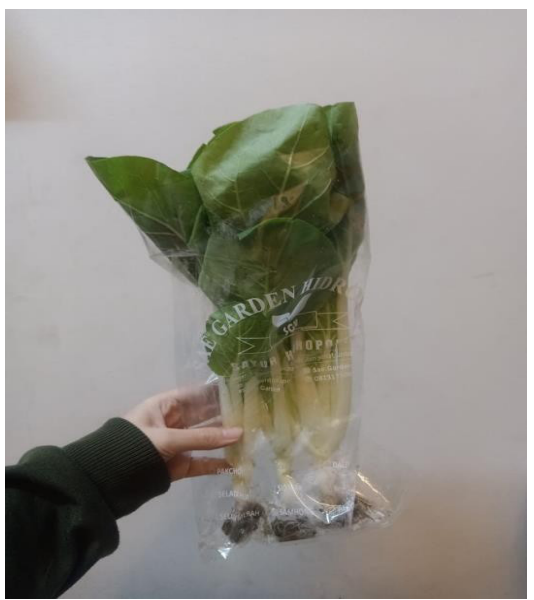

Figure 10. The plant in package to be sold (Pak Choi) 


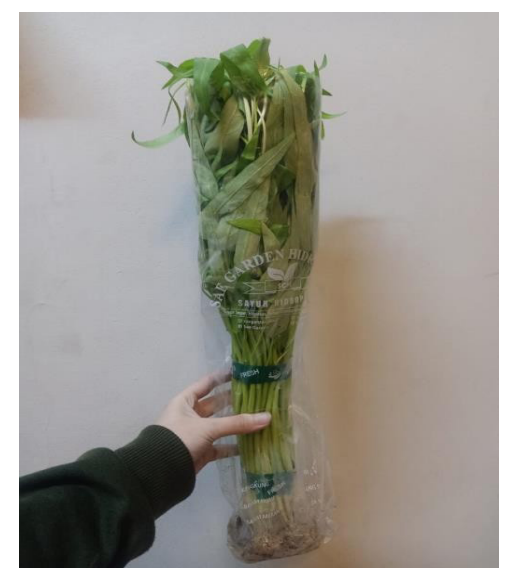

Figure 11. The plant in package to be sold (Kangkung)

\section{Saegardenfarm.com}

Here are some images of this website:

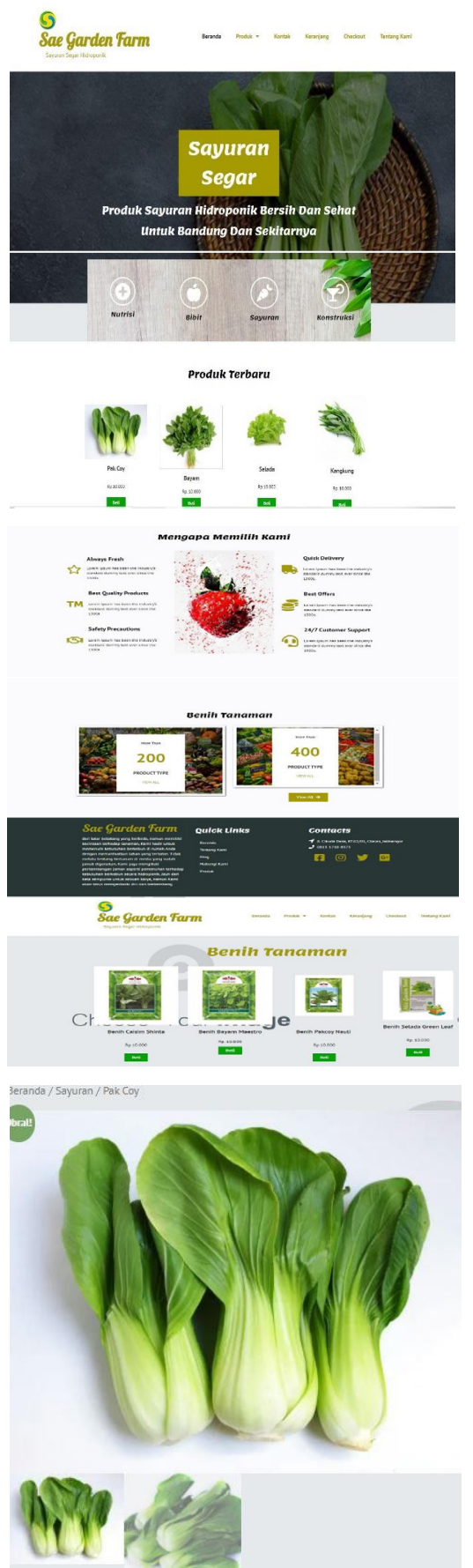

Website saegarden.com is under construction

All members of team from Binus University are developing a new website because the owner does not want to use the older website anymore. In this situation, the design of Mobile App will continue after finishing this website.

\section{CONCLUSION}

MSIMs Sae Garden Farm has a problem in promoting their products especially in Pandemic time but the team of Binus University are in progress to help this farm. The team whose members are from two lecturers an two student of Computer Science Department and Entrepreneurship Department are good to help them in building website with e-commerce and will continue in design of mobile application and digital marketing.

\section{REFERENCE}

[1] "8 Cara Membuat Kebun Tanaman Hidroponik Sendiri di Rumah.” https://www.idntimes.com/ life/diy/dian- arthasalina/8-langkah-mudah-bikinkebun-hidroponik-sendiri-di-rumah/8 (accessed Oct. 27, 2020).

[2] "Cara Menanam Hidroponik dengan Wick System untuk Pemula." https:/www.caramenanam.org/ hidroponik -sistem-wick/ (accessed Oct. 27, 2020).

[3] "12 Jenis Tumbuhan Hidroponik, Jangan Asal Pilih - Hot Liputan6.com." https://hot.liputan6.com/ read/4370104/12- jenis-tumbuhan-hidroponikjangan-asal- pilih (accessed Oct. 27, 2020).

[4] "How to Hydroponic 4rd Edition - Keith Roberto. pdf.pdf - Google Drive.” https://drive.google.com/ file/d/0B- VfIDEPHBAcaWIxbFAzenZnSzA/ view (accessed Oct. 27, 2020).

[5] "Buku Hidroponik PDF Gratis - Berkas Edukasi." https://www.berkasedukasi.com/2018/09/ bukuhidroponik-pdf-gratis.html (accessed Oct. 27, 2020).

[6] "Hobby Hydroponic Second Edition - Howard M. Resh.pdf - Google Drive." https://drive.google. com/file/d/0B-VfIDEPHBAcQTZWZjIwR0lkYzA/ view (accessed Oct. 27, 2020).

[7] "Gardening Indoors with Soil \& Hydroponics , Fifth Edition - George F Van Patten.pdf Google Drive." https:/drive.google.com/file/ d/0B- VfIDEPHBAcZIRicWxQR3ZYRDA/view (accessed Oct. 27, 2020).

[8] "Hydroponic Food Production - A Definitive Guidebook (7th Ed) - Howard M. Resh.pdf Google Drive." https://rive.google.com/file/ d/0B- VfIDEPHBAcVTBwYmk1SVF2Ums/view (accessed Oct. 27, 2020). 
[9] "hydroponic Recipes - Neils S Mattson.pdf - Google Drive." $\quad$ https://drive.google.com/file/d/0BVfIDEPHBAcZmh6VWR4WVhNWmM/vie w (accessed Oct. 27, 2020).

[10] "hydroponic Nutrients - An easy way to make your own - M. Edward Muckle.pdf - Google Drive." https://drive.google.com/file/d/0BVfIDEPHBAca0FjQ1REVEJ5MjA/view (accessed Oct. 27, 2020).

[11] “Commercial Hydroponics 3rdEdition - John Mason. pdf - Google Drive.” https://drive.google.com/file/ d/0B- VfIDEPHBAceTcwMHFKdmtuZXc/view (accessed Oct. 27, 2020).

[12] "Skenario Pemerintah Mendukung Pemulihan UMKM dan Koperasi dari..." https://ekbis. sindonews.com/read/173352/34/skenariopemerintah-mendukung- pemulihan-umkm-dankoperasi-dari-hulu- ke-hilir-1600808946 (accessed Oct. 28, 2020).

[13] "Ingin Ikut Pelatihan UMKM Go Digital dari Tokopedia dan Kemkominfo? Cek Caranya di Sini - Tekno Liputan6.com.” https://www.liputan6.com/ tekno/read/438 7415/ingin-ikut-pelatihan-umkmgo- digital-dari-tokopedia-dan-kemkominfo- cekcaranya-di-sini (accessed Oct. 27, 2020).

[14] "3 Strategi Bantu UMKM Lebarkan Sayap ke Luar Negeri: Okezone Economy." https://economy.okezone.com/read/2020/ 10/28/320/2300898/3-strategi-bantu- umkmlebarkan-sayap-ke-luar-negeri (accessed Oct. 28, 2020).
[15] "Why Brand Awareness Matters," CMSWire.com, Accessed: Oct. 27, 2020. [Online]. Available: https://www.cmswire.com/digital- marketing/ why-brand-awareness- matters/.

[16] "Digital Marketing Dapat Bantu UMKM Bertahan di Tengah Pandemi Covid-19 - Tekno Liputan6. com." https://www.liputan6.com/tekno/read/438 9060/digital-marketing-dapat-bantu- umkmbertahan-di-tengah-pandemi- covid- 19?utm source=BD\&utm_medium=Partn ership\&utm campaign=yahoo\&yptr=yaho o (accessed Oct. 27, 2020).

[17] "Digital Marketing Adalah - Pengertian, Konsep, Jenis Dan Contoh." https://www.dosenpendidikan. co.id/digital-marketing-adalah/ (accessed Oct. 27, 2020).

[18] M. Kates, Making digital and traditional marketing work together. Econsultancy, 2013.

[19] K. Schiele and S. Chen, "Design Thinking and Digital Marketing Skills in Marketing Education: A Module on Building Mobile Applications," Mark. Educ. Rev., vol. 28, no. 3, pp. 150-154, Sep. 2018, doi: 10.1080/10528008.2018.1448283.

[20] C. Brinkley, Digital marketing is growing in Australia, but so is the skills gap. Econsultancy, 2012.

[21] M. T. P. M. B. Tiago and J. M. C. Veríssimo, "Digital marketing and social media: Why bother?," Bus. Horiz., vol. 57, no. 6, pp. 703-708, 2014, doi: 10.1016/j.bushor.2014.07.002 